\title{
AKIBAT HUKUM KEPAILITAN BADAN USAHA MILIK NEGARA PASCA BERLAKUNYA UNDANG-UNDANG NOMOR 17 TAHUN 2003 TENTANG KEUANGAN NEGARA
}

\author{
Putu Edgar Tanaya \\ Fakultas Hukum Universitas Udayana \\ Jalan Pulau Bali No. 1 Denpasar \\ Email : edgartanaya43@gmail.com \\ Kadek Agus Sudiarawan \\ Fakultas Hukum Universitas Udayana \\ Jalan Pulau Bali No. 1 Denpasar \\ Email : degust_ugm30@yahoo.co.id
}

\begin{abstract}
ABSTRAK
BUMN merupakan badan hukum yang tunduk kepada prinsip-prinsip badan hukum. BUMN dalam menjalankan aktifitas bisnisnya dapat melakukan inefficiency yang menyebabkan ketidakmampuan BUMN untuk memenuhi kewajibannya (utang) kepada kreditor. Dalam hal BUMN memiliki utang kepada minimal 2 (dua) orang kreditor dan salah satunya telah jatuh tempo, maka BUMN dapat dimohonkan pailit oleh kreditor. BUMN yang dinyakan pailit oleh pengadilan niaga akan memberikan akibat hukum terhadap para pihak. Selain itu, kepailitan BUMN akan memberikan akibat hukum kepada negara pasca lahirnya Undang-Undang Nomor 17 Tahun 2003 tentang Keuangan negara. Pasca lahirnya Undang-Undang Nomor 17 Tahun 2003 tentang Keuangan negara, ketika utang debitor lebih besar dari jumlah aset BUMN maka negara secara tanggung renteng ikut serta bertanggung jawab membayar utang BUMN dengan menggunakan APBN. Hal ini sebagai akibat status kekayaan negara dan BUMN tidak terpisah.
\end{abstract}

Kata Kunci: BUMN, Kepailitan, Harta Kekayaan Terpisah

\section{ABSTRACT}

State owner enterprises is a legal entity that is subject to the principles of legal entities. State owner enterprises in running its business activities can perform inefficiency that causes the inability of state owner enterprises to meets its obligation (debts) to creditors. In the case of state owner enterprises has a debt to a minimum of two the creditor and one of them has matured, the state owner enterprises can be petitioned for bankcuptcy by creditors. For the state owner enterprises which bankcruptcy declare by the comercial court will give legal effect to the parties. In addition, the bankruptcy of state owner enterprises will give legal effect to the state enactment of Law No. 17 of 2003 on Law Finances. Post-enactment of Law No. 17 of 2003 on Law Finances, when the debitor's debt more than the total assets of state owner enterprises, the state shall be mutually participate responsible for paying the debt of state owner enterprises using state budget. This is as a result status of the country's and state owner enterprises's wealth are not detached.

Keyword: state owner enterprises , Bankruptcy, detached wealth 


\section{Pendahuluan}

Indonesia adalah negara

kesejahteraan (welfare state) yaitu negara yang pemerintahannya bertanggung jawab penuh untuk memnuhi kebutuhan dasar sosial dan ekonomi setiap warga negara guna menjamin suatu standar hidup yang minimal (terpenuhi) (Karma Resen, 2015;1). Hal ini sesuai dengan alinea ke IV pembukaan Undang-Undang Dasar Negara Republik Indonesia 1945 (UUDNRI 1945) bahwa “...untuk membentuk suatu Pemerintahan Negara Indonesia yang,...memajukan kesejahteraan umum,...keadilan sosial,...". Sehingga keberadaan negara menjadi suatu keniscayaan bagi masyarakat Indonesia.

Negara diberikan wewenang untuk menguasai cabang-cabang produksi yang penting dan bidang yang berkaitan dengan hajat hidup orang banyak (Pasal 33 ayat (2) UUDNRI). Pendirian Badan Usaha Milik Negara (BUMN) merupakan fungsi negara sebagai enterpreneur (Friedmann, 1971;3) untuk mengelola bidang-bidang yang berkaitan dengan hajat hidup orang banyak. Sehingga perkembangan BUMN menjadi penentu keberlanjutan pembangunan nasional untuk mewujudkan kesejahteraan bagi masyarakat.

Pengaturan mengenai BUMN diatur secara umum dalam UndangUndang Nomor 40 Tahun 2007 tentang Perseroan Terbatas (selanjutnya disebut UUPT 2007) dan UndangUndang Nomor 23 Tahun 2003 tentang Badan Usaha Milik Negara (selanjutnya disebut UUBUMN). Berdasarkan pengaturan UUBUMN BUMN di Indonesia terbagi menjadi 2 (dua) bentuk yakni PT (Persero) dan Perum. Persero dibebankan untuk mencari keuntungan sedangkan Perum lebih dibebankan untuk melaksanakan pelayanan kepada masyarakat (public utility) Sedangkan Perusahaan Jawatan (Perjan) dihapuskan setelah berlakunya UUBUMN.

BUMN beraktivitas layaknya perusahaan lain, tujuannya adalah mencari keuntungan (termasuk pelayanan kepada masyarakat). BUMN dalam mengembangkan perusahaan, bekerjasama dengan pihak lain seperti lembaga keuangan. Namun, semakin tinggi peluang untuk mencari keuntungan maka semakin tinggi juga resiko yang berakibat kerugian bagi BUMN. BUMN dalam perjalanannya sangat mungkin mengalami kerugian karena berbagai faktor seperti manajemen yang kurang baik, situasi politik, ekonomi, hukum yang kurang baik dan lain sebagainya. Kerugian yang dialami BUMN berakibat tidak terpenuhinya kewajiban membayar utang kepada kreditor.

Pada tahun 2004, lahir UndangUndang 37 Tahun 2004 tentang Kepailitan dan Penundaan Kewajiban Pembayaran Utang (selanjutnya disebut UUKPKPU) sebagai pengganti UndangUndang Nomor 4 Tahun 1998 tentang Kepailitan. UUKPKPU lahir sebagai respon terjadinya krisis moneter yang terjadi diseluruh dunia, termasuk di Indonesia. Lahirnya UUKPKPU memberikan perlingungan bagi para pihak, baik kreditor maupun debitor.

Berdasarkan pengaturan UUKPKPU, setiap orang atau badan hukum dapat dipailitkan dengan syarat: (1) terdapat utang; (2) terdapat 2 (dua) atau lebih kreditor; dan (3) salah satu utang telah jatuh tempo. Berdasarkan 3 syarat yang sangat sederhana tersebut BUMN dapat memohon dan dimohonkan pailit kepada pengadilan niaga.

Pasca berlakunya UUKPKPU, permohonan kepailitan yang dimohonkan baik oleh debitor maupun 
oleh kreditor meningkat pesat, tidak terkecuali permohonan kepailitan suatu BUMN. Putusan kepailitan Telkomsel (persero) menjadi salah satu permohonan kepailitan yang menimbulkan debatable pada tahun 2012. Perdebatan muncul karena jumlah utang Telkomsel tidak lebih banyak dari jumlah aset yang dimiliki Telkomsel.

Pada tahun 2003 lahir UndangUndang Nomor 17 Tahun 2003 tentang Keuangan Negara (selanjutnya disebut UU Keuangan Negara). Pasal 2 g UU Keuangan Negara mengatur bahwa ruang lingkup keuangan negara bukan hanya pemasukan dan pengeluaran negara, namun termasuk juga kekayaan BUMN. Akibatnya, antara kekayaan BUMN dengan kekayaan negara merupakan kekayaan yang tidak terpisahkan. Padahal Pasal 1 UUBUM mengatur bahwa kekayaan negara dengan kekayaan BUMN merupakan kekayaan terpisah walaupun penyertaan modal berasal dari keuangan negara. Hal ini tentunya menimbulkan disharmoni antara pengaturan UU Keuangan Negara dan UUBUMN.

Kepailitan BUMN tentunya menimbulkan akibat hukum baik bagi debitor dan kreditor. Kemudian berdasarkan pengaturan Pasal 2 g UU Keuangan Negara tentunya juga akan menimbulkan akibat hukum terhadap negara karena kekayaan negara dengan kekayaan BUMN tidak terpisah. Berdasarkan latar belakang di atas menjadi menarik untuk dikaji mengenai akibat hukum kepailitan BUMN terhadap para pihak serta akibat hukum kepailitan BUMN terhadap negara pasca lahirnya Undang-Undang Keuangan Negara.

\section{Pengaturan Kepailitan Badan Usaha Milik Negara (Bumn)}

\section{Persyaratan Kepailitan}

BUMN merupakan badan hukum (legal entity) yang mandiri dan otonom layaknya badan hukum swasta lain. Sehingga BUMN dapat mencari keuntungan (profit oriented) dan dapat pula mengalami kerugian dari aktifitas bisnis yang dilakukan. Utang yang dimiliki BUMN dapat dibayarkan melalui mekanisme kepailitan sesuai dengan persyaratan yang ditentukan UUKPKPU.

UUKPKPU tidak mengenal perbedaan pengaturan kepailitan antara BUMN dengan badan hukum swasta, sehingga BUMN juga tunduk pada pengaturan kepailitan UUKPKPU. Persyaratan kepailitan suatu perusahaan diatur dalam Pasal 2 ayat (1) UUKPKPU. Pasal tersebut mengatur bahwa debitor yang mempunyai 2 (dua) atau lebih kreditor dan tidak membayar lunas sedikitnya terdapat satu utang yang sudah jatuh tempo. Berdasarkan pengaturan tersebut ada 3 (tiga) persyaratan untuk dapat mengajukan permohonan kepailitan, yaitu: (1) harus ada utang; (2) salah satu utang telah jatuh tempo dan dapat ditagih; dan (3) terdapat 2 (dua) atau lebih kreditor.

Syarat pertama mengajukan permohonan kepailitan adalah utang, pengertian utang diatur dalam Pasal 1 angka 6 UUKPKPU. Utang merupakan kewajiban yang harus dibayarkan debitor kepada kreditor/para kreditor. Utang tersebut dibayarkan dalam bentuk uang mata uang Indonesia maupun mata uang asing, baik secara langsung maupun yang ada di masa yang akan datang, yang timbul karena perjanjian utang piutang ataupun berdasarkan ketentuan yang diatur dalam undang-undang. Kreditor dapat menuntut pembayaran dari harta debitor, jika debitor tidak membayar utangnya. 
Syarat yang kedua adalah salah satu utang telah jatuh tempo dan dapat ditagih. Setiap perjanjian utang piutang pasti mencantumkan jangka waktu pembayaran utang debitor kepada debitor. Suatu utang yang telah jatuh tempo harus dibayarkan kepada kreditor

Syarat yang ketiga terdapat 2 atau lebih kreditor. Dalam pengaturan UUKPKPU cukup dengan minimal 2 utang dapat mengajukan permohonan kepailitan. UUKPKPU hanya mengatur jumlah minimal kreditor untuk dapat mempailitkan debitor. Ketiga persyaratan mengajukan permohonan kepailitan yang diatur UUKPKPU sangat sederhana.

Persyaratan kepailitan Pasal 2 ayat (1) UUKPKPU sangat sederhana. Pasal tersebut tidak mengatur syarat minimal utang yang dimiliki debitor, sehingga utang yang memiliki jumlah sangat kecil dapat dipailitkan oleh kreditor. Pasal tersebut juga tidak mengatur kemampuan debitor untuk membayar utang (perbandingan jumlah utang dan aset). Berdasarkan pengaturan UUKPKPU tersebut, yang dilihat dari debitor hanya ketidakmauan debitor membayar utang, bukan kemampuan debitor untuk membayar utang kepada debitor. Sehingga membuka peluang dipailitkannya perusahaan-perusahaan (termasuk BUMN) walaupun jumlah utang perusahan tersebut tidak lebih banyak dari jumlah aset. Padahal seharusnya kepailitan menjadi ultimum remmidium/last resort.

Putusan kepailitan Telkomsel (persero) menjadi salah satu permohonan kepailitan yang menimbulkan debatable pada tahun 2012. Perdebatan muncul karena jumlah utang Telkomsel tidak lebih banyak dari jumlah aset yang dimiliki Telkomsel. Persyaratan yang sangat sederhana tersebut akan merugikan debitor karena harus dipailitkan padahal jumlah asetnya jauh lebih besar dari jumlah utangnya. Bahkan jumlah utang Telkomsel sebesar Rp. 5.260 .000 .000 hanya $0,4 \%$ dari laba Telkomsel pada tahun 2011 yang mencapai Rp. 12.823.670.058.017 (https://m.tempo.co). Permohonan kepailitan kreditor pada dikabulkan oleh Hakim Pengadilan Niaga Jakarta Pusat. Namun akhirnya Pengadilan Tinggi Jakarta Pusat mengabulkan banding yang diajukan pihak Telkomsel dan MA menolak kasasi yang diajukan oleh kreditor. Berdasarkan hal tersebut Telkomsel sebenarnya sangat mampu untuk membayar utangnya. Persyaratan ini menjadi urgent untuk direvisi untuk keberlangsungan suatu perusahaan terutama dalam hal ini BUMN, karena BUMN diberikan tanggung jawab oleh konstitusi (Pasal 33 ayat (2) UUDNRI) untuk mengelola bidang-bidang yang berkaitan dengan hajat hidup orang banyak untuk kepentingan kesejahteraan masyarakat.

UUKPKPU dibandingkan dengan negara lain, dibeberapa negara lain sudah dingatur mengenai jumlah minimal utang. Peraturan kepailitan Malaysia mengatur bahwa syarat untuk dapat mengajukan permohonan kepailitan ke pengadilan adalah debitor tidak mampu membayar utang kepada kreditor. Jumlah utang debitor tersebut harus minimal 30.000 Ringgit Malaysia. Negara Inggris mengatur jumlah minimal utang debitor untuk dapat mengajukan permohonan kepailitan adalah £200. Kemudian di Negara Australia minimal \$1.500, dan Singapura minimal $\$ 10.000$ (Wijayanta, 2013;11).

Dilihat dari perspektif ekonomi makro, sangat urgent untuk merevisi persyaratan kepailitan suatu badan hukum (termasuk BUMN) dengan menambahkan jumlah minimal utang. 
Alasannya, dengan mudahnya kreditor mempailitkan suatu badan hukum (terutama BUMN) akan menimbulkan dampak ekonomi sistemik dan tentunya hal tersebut akan berdampak terhadap menurunnya iklim investasi asing ke Indonesia.

\section{Kepailitan Orang dan Badan Hukum}

Orang dan badan hukum merupakan subyek hukum sebagai pendukung hak dan kewajiban. Orang menjadi subyek hukum secara otomatis ketika ia dilahirkan. Bahkan seseorang dianggap sebagai subyek hukum ketika masih di dalam kandungan, apabila kepentingan anak mengkehendaki (Pasal 2 Kitab Undang-Undang Hukum Perdata ) (berlaku surut). Sedangkan badan hukum merupakan subyek hukum hasil konstruksi yuridis yang beraktifitas layaknya manusia (teori organ) (Chidir Ali, 2014; 32).

UUKPKPU mengatur subyek

hukum yang dapat dipailitkan adalah orang dan badan hukum. UUKPKPU tidak membedakan pengaturan kepailitan orang dan badan hukum. persyaratan kepailitan yang diatur dalam UUKPKPU berlaku bagi orang maupun badan hukum. Sehingga orang juga tunduk pada ketiga persyaratan dalam UUKPKPU yakni utang, utang sudah jatuh tempo dan dapat ditagih, dan terdapat 2 (dua) atau lebih kreditor. Persyaratan kepailitan bagi orang sama halnya dengan badan hukum, yakni terlalu sederhana.

Kepailitan orang juga seharusnya memiliki jumlah minimal utang untuk dapat dipailitkan. Diaturnya minimal jumlah utang akan menghindari dipailitkannya seorang debitor yang mempunyai utang tidak lebih banyak dari junlah asetnya. Namun tentunya jumlah minimal utang antara orang dan badan hukum harus dibedakan. Jumlah minimal utang badan hukum seharusnya lebih besar dari orang mengingat antara badan hukum dan orang memiliki karakeristik yang berbeda. Bahkan di Pasal 32 ayat (1) UUPT 2007, sebagai persekutuan modal badan hukum memiliki modal hasil dari penyetoran modal pemegang saham minimal sebesar Rp. 50.000.000. Secara rasional seharusnya jumlah mininal utang badan hukum lebih besar dari jumlah minimal utang orang sebagai syarat permohonan kepailitan.

\section{Status Keuangan BUMN Sebagai Badan Hukum}

BUMN merupakan badan hukum. Badan hukum memiliki beberapa unsur yakni: (1) perkumpulan orang (2) dapat melakukan perbuatan hukum dalam hubungan-hubungan hukum (3) adanya harta kekayaan yang terpisah; (4) mempunyai pengurus; (5) mempunyai hak dan kewajiban; dan (6) dapat digugat atau menggugat di depan pengadilaN (Chidir Ali, 2014,21). Unsurunsur tersebut mutlak harus dimiliki suatu badan hukum.

Harta kekayaan terpisah merupakan salah satu unsur badan hukum. Kekayaan terpisah menjadi ciri bahwa badan hukum merupakan suatu persekutuan modal sedangkan badan usaha yang tidak berbadan hukum merupakan persekutuan orang. Harta kekayaan terpisah mengandung arti bahwa antara harta kekayaan pemegang saham dengan dengan harta kekayaan suatu badan hukum terpisah (limited liability). Pasal 3 ayat (1) UUPT tentang PT mengatur bahwa "Pemegang saham perseroan tidak bertanggungjawab secara pribadi atas perikatan yang dibuat atas nama perseroan dan tidak bertanggung jawab atas kerugian perseroan melebihi saham yang dimiliki. Kemudian Pasal 39 UUBUMN mengatur bahwa "menteri tidak bertanggung jawab atas segala perbuatan hukum yang 
dibuat oleh perum dan tidak bertanggung jawab atas kerugian perum melebihi nilai kekayaan negara yang telah dipisahkan ke dalam perum". Bahkan walaupun mendapat suntikan dana dari negara, suntikan dana itu tetap dihitung sebagai utang BUMN (Abdulkadir Muhammad;101). Hal ini membuktikan bahwa suatu badan hukum otonom dan mandiri.

Pada tahun 2003 lahir UU keuangan negara yang merupakan paket kebijakan ekonomi di era Presiden Susilo Bambang Yudhoyono. Pasal 2 g UU Keuangan negara mengatur bahwa yang termasuk ruang lingkup keuangan negara termasuk kekayaan BUMN. Hal ini tentu bertentangan prinsip badan hukum bahwa setiap badan hukum memiliki harta kekayaan terpisah. Dilihat dari sumber modal BUMN, memang benar modal pendirian BUMN berasal dari penyertaan keuangan negara. Namun ketika pendirian suatu BUMN terjadi transformasi status keuangan, yakni dari keuangan negara (public sector) menjadi keuangan BUMN (privat sector) (Atmadja, 2010). Transformasi status keuangan hakikatnya merupakan konsekuensi logis dari konsep dan prinsip badan hukum. Sehingga setiap BUMN tunduk pada konsep dan prinsip badan hukum ketika terjadi transformasi status keuangan dari publik menjadi privat.

Pasal 1 UUBUMN sendiri sebenarnya sudah menegaskan bahwa antara kekayaan negara dan kekayaan BUMN merupakan kekayaan terpisah. Bahkan Pasal 11 UUBUMN mengatur bahwa BUMN tunduk pada prinsipprinsip yang berlaku bagi perseroan terbatas sebagaimana diatur dalam Undang-Undang Nomor 1 Tahun 1995 tentang Perseroan Terbatas yang kemudian digantikan oleh UndangUndang Nomor 40 Tahun 2007 tentang Perseroan terbatas. Hal itu membuktikan bahwa BUMN juga harus tunduk kepada konsep dan prinsip yang berlaku bagi perseroan terbatas.

Sebagai contoh, suatu BUMN yang memiliki anak perusahaan menjadi debatable mengenai status anak perusahaan tersebut, BUMN atau tidak. Jika kembali merujuk kepada prinsip kekayaan terpisah, status anak perusahaan BUMN tersebut bukan sebagai BUMN melainkan badan hukum swasta walaupun modal pendirian anak perusahaan tersebut berasal dari penyertaan langsung harta kekayaan BUMN. Contoh lain, Temasek Holding Company merupakan BUMN milik Singapura. Temasek memiliki beberapa anak perusahaan yang membeli saham mayoritas Telkomsel dan Indosat yang menyebabkan terjadi praktek persaingan usaha tidak sehat dan monopoli. Kemudian menjadi debatable pertanggungjawaban Temasek terhadap praktek yang dilakukan oleh kedua anak perusahaannya. Bila mengacu kepada prinsip kekayaan terpisah, temasek merupakan badan hukum yang otonom dan mandiri sehingga secara yuridis tidak terikat dengan anak perusahaannya. Pada putusan Komisi Pengawas Persaingan Usaha (KPPU) yang dijadikan dasar Temasek bersalah adalah keterikatan secara ekonomi (single economic entity) bukan keterikatan secara yuridis dengan anakanak perusahaannya.

\section{Akibat Hukum Kepailitan BUMN}

\section{Akibat Hukum kepailitan BUMN Terhadap Debitor dan Kreditor} BUMN yang telah memenuhi persyaratan pailit sesuai ketentuan UUKPKPU dapat dimohonkan pailit oleh kreditor kepada pengadilan niaga. Ketika pengadilan niaga memutuskan bahwa suatu BUMN telah pailit, maka ada beberapa akibat hukum yang diakibatkan. Putusan pailit suatu BUMN 
mengakibatkan seluruh kekayaan BUMN serta segala sesuatu yang diperoleh selama kepailitan berada dalam sitaan umum sejak putusan pernyataan pailit diucapkan (Pasal 24 ayat (1) UUKPKPU). BUMN kehilangan haknya untuk berbuat sesuatu terhadap penguasaan dan pengurusan harta kekayaan yang termasuk dalam kepailitan semenjak tanggal diterbitkan putusan (dihitung dari pukul 00.00 waktu setempat) (Pasal 24 ayat (2) UUKPKPU) yang menyatakan BUMN pailit. Kurator yang diberikan kewenangan untuk pengurusan dan pemberesan harta pailit (Pasal 69 ayat (1) UUKPKPU).

Walaupun harta pailit diurus dan dibereskan kurator namun Pasal $22 \mathrm{a}, \mathrm{b}$, c UUKPKPU memberikan pengecualian terhadap beberapa hal yakni: (Jono, 2010;107) (1) benda, termasuk hewan yang benar-benar-benar dibutuhkan oleh debitor sehubungan dengan pekerjaannya, perlengkapannya, alatalat medis yang dipergunakan untuk kesehatan, tempat tidur, dan perlengkapannya yang dipergunakan oleh debitor dan keluarganya, dan bahan makanan untuk 30 hari bagi debitor dan keluarganya, yang terdapat di tempat itu; (2) segala sesuatu yang diperoleh debitor dari pekerjaannya sendiri sebagai penggajian dari suatu jabatan atau jasa, sebagai upah, pensiun, uang tunggu atau uang tunjangan, sejauh yang ditentukan oleh hakim pengawas; atau (3) uang yang diberikan kepada debitor untuk memenuhi suatu kewajiban memberi nafkah menurut undang-undang. Jadi ketika BUMN dinyatakan pailit, BUMN tidak lagi punya hak untuk menguasai dan mengurus harta kekayaannya namun BUMN masih dapat melakukan perbuatan hukum lain sepanjang tidak menyentuh harta kekayaan karena sudah berada di bawah sita umum.
Kepailitan BUMN menimbulkan akibat hukum terhadap perikatan yang dibuat setelah putusan pailit. Pasca putusan pailit, setiap perikatan yang lahir yang menimbulkan kerugian terhadap pihak lain tidak dapat dibayar dari harta pailit, kecuali perikatan tersebut menguntungkan harta pailit (Pasal 25 UUKPKPU).

Kepailitan BUMN juga menimbulkan akibat hukum terhadap perbuatan hukum BUMN yang dilakukan sebelum putusan pernyataan pailit diucapkan. Pasal 41 ayat (1) UUKPKPU menegaskan bahwa segala perbuatan hukum debitor yang telah dinyatakan pailit yang merugikan kepentingan kreditor yang dilakukan sebelum putusan pernyataan pailit diucapkan, dapat dimintakan pembatalan kepada pengadilan. Sistem pembuktian pasal tersebut adalah sistem pembuktian terbalik, dimana debitor dan pihak ketiga harus membuktikan bahwa perbuatan hukum yang dilakukannya tidak merugikan harta pailit.

Putusan pailit BUMN tidak hanya menimbulkan akibat hukum bagi debitor tapi juga menimbulkan akibat hukum bagi kreditor. Pasca putusan pailit kreditor tidak berhak meminta pembayaran utang secara sepihak melainkan diurus dan dibereskan oleh kurator di bawah pengawasan hakim pengawas (Pasal 1 angka 1 UUKPKPU). Pengangkatan kurator didasarkan pada putusan pernyataan pailit, dalam arti bahwa dalam putusan pernyataan pailit harus dinyatakan adanya pengangkatan kurator (Pasal 15 ayat (1) UUKPKPU).

Kedudukan para kreditor pada dasarnya sama (paritas creditorium). Para kreditor memiliki kedudukan yang sama sesuai dengan besarnya utang (tagihan) masing-masing (pari passu pro rata parte). 
Kreditor yang mempunyai hak atas harta pailit dikelompokan menjadi 3 (tiga) yaitu: kreditor separatis, kreditor preferen, dan kreditor konkuren. Kreditor separatis adalah kreditor pemegang hak jaminan kebendaan (hak jaminan kebendaan terdiri dari hak gadai, hipotek, hak tanggungan, dan jaminan fidusia ), yang dapat bertindak sendiri (Imran Nating, 2005). Kreditor separatis tidak terpengaruh dengan putusan pernyataan pailit debitor (Pasal 61 UUKPKPU ). Kreditor separatis tetap dapat menjalan hak eksekusi terhadap jaminan kebendaan secara sepihak dan tidak terpengaruh terhadap putusan kepailitan debitor. Hasil penjualan jaminan kebendaan tersebut digunakan untuk membayar piutang kreditor.

Kreditor preferen merupakan kreditor yang diistimewakan karena sifat piutangnya dan mendapat hak untuk memperoleh pelunasan lebih dahulu dari penjualan harta pailit. Kreditor istimewa berada di bawah pemegang hak kebendaan (Imran Nating;51), namun atas tuntutan kurator atau kreditor yang diistimewakan yang kedudukannya lebih tinggi dari dari pemegang hak kebendaan maka kreditor pemegang hak tersebut menyerahkan bagian dari hasil penjualan tersebut wajib untuk jumlah yang sama dengan jumlah tagihan yang diistimewakan (Pasal 60 ayat (2) UUKPKPU).

Kreditor konkuren merupakan kreditor bersaing (Imran Nating). Asas paritas creditorum berlaku pada kreditor konkuren. Para kreditor konkuren mempunyai hak yang yang sama sesuai dengan besarnya piutang yang mereka miliki. Kreditor konkuren mendapat bagian pembayaran piutang setelah dikurangi dengan pembayaran piutang kreditor separatis dan kreditor preferen.

\section{Akibat Hukum Terhadap Negara Pasca Berlakunya UU Keuangan Negara}

BUMN tunduk pada prinsipprinsip badan hukum pasca terjadi transformasi status keuangan dari keuangan publik (keuangan negara) menjadi keuangan privat (keuangan BUMN).

Pasal 11 UUBUMN menyatakan bahwa BUMN tunduk kepada prinsipprinsip perseroan yang diatur oleh UUPT 2007. Pasal 3 UUPT 2007 menyatakan bahwa pemegang saham tidak bertanggung jawab secara pribadi atas perikatan yang dibuat atas nama perseroan dan tidak bertanggung jawab atas kerugian perseroan yang melebihi saham yang dimiliki (limited liability), hal tersebut membuktikan bahwa adanya kekayaan terpisah antara kekayaan pemegang saham dengan kekayaan BUMN.

$$
\text { Ketentuan Pasal } 3 \text { ayat (1) }
$$

tersebut tidak berlaku bila: (1) persyaratan perseroan sebagai badan hukum belum atau tidak terpenuhi; (2) pemegang saham yang bersangkutan baik langsung maupun tidak langsung dengan itikad buruk memanfaatkan perseroan untuk kepentingan pribadi; (3) pemegang saham yang bersangkutan terlibat dalam perbuatan melawan hukum yang dilakukan oleh perseroan; atau (4) pemegang saham yang bersangkutan baik langsung maupun tidak langsung secara melawan hukum menggunakan kekayaan perseroan menjadi tidak cukup untuk melunasi utang perseoran. Hal tersebut membuktikan bahwa dalam keadaan seperti di atas, antara kekayaan pemegang saham dan kekayaan BUMN tidak terpisah sehingga setiap kerugian yang dialami BUMN juga menjadi tanggung jawab pemegang saham 
sampai harta pribadi (piercing the corporate veil)

Lahirnya UU Keuangan negara yang memperluas ruang lingkup keuang negara sampai harta kekayaan BUMN yang dipisahkan menimbulkan akibat hukum dalam kepailitan BUMN. Akibat hukum lahirnya UU Keuangan negara terhadap kepailitan BUMN adalah harta pailit yang harus dibayarkan kepada kreditor tidak hanya berasal dari harta kekayaan BUMN namun dalam hal jumlah utang lebih besar dari jumlah kekayaan BUMN harus ikut ditanggung oleh negara. Hal ini sebagai konsekuensi tidak adanya pemisahaan harta kekayaan negara dengan harta kekayaan BUMN. Kondisi demikian tentunya akan membebankan keuangan negara jika setiap kepailitan BUMN harus ditanggung juga oleh keuangan negara. Kepailitan BUMN menjadi hal yang sangat possible terjadi karena sebagian besar BUMN belum berjalan secara profesional sebagai akibat terlalu banyaknya intervensi negara terhadap aktifitas bisnis BUMN. Negara sebagai pemegang saham seharusnya berhak mengintervensi aktifitas bisnis BUMN hanya melalui Rapat Umum Pemegang Saham (RUPS). ${ }^{1}$

Berdasarkan hal tersebut sangat urgent untuk merevisi UU Keuangan Negara (terutama Pasal 2g) mengingat permohonan judicial review UU keuangan negara ditolak oleh Mahkamah Konstitusi. Revisi UU Keuangan negara akan memaksimalkan kinerja BUMN untuk mengelola bidang yang berkaitan dengan hajat hidup orang banyak sehingga kesejahteraan sebagai tujuan negara dapat diwujudkan bagi seluruh rakyat Indonesia.

\section{Simpulan}

berdasarkan pembahasan di atas ada beberapa kesimpulan yang didapat, yaitu: (1) kepailitan BUMN menimbulkan akibat hukum bagi debitor dan kreditor. Kepailitan BUMN berakibat hilangnya hak debitor untuk mengurus dan menguasai harta pailit. Pasca putusan pailit pengurusan dan penguasaan harta debitor diserahkan kepada kurator yang merupakan pihak yang diberikan kewenangan oleh undang-undang. Kepailitan BUMN juga berakibat hilangnya hak kreditor untuk mengeksekusi harta pailit secara sepihak dan diserahkan kepada kurator sesuai dengan kedudukan kreditor tersebut; (2) kepailitan BUMN juga menimbulkan akibat hukum bagi negara pasca berlakunya UU Keuangan Negara. Kepailitan BUMN menimbulkan akibat hukum ikutsertanya negara bertanggung jawab atas utang yang harus dibayarkan oleh BUMN kepada kreditor dalam hal jumlah utang BUMN lebih besar dari jumlah karena antara kekayaan negara dan kekayaan BUMN tidak terpisah.

\section{Daftar Pustaka}

\section{Buku}

Ali, Chidir, 2014, Badan Hukum, PT Alumni, Bandung.

Atmadja, Arifin P. Soeria, 2010, Keuangan Publik dalam Perspektif Hukum (Teori, Praktik, dan Kritik), cetakan ke-2, PT. Raja Grafindo Persada, Jakarta

Friedmann, W., 1971, The state and the Rule of Law in a Mixed Economy, Steven and Sons, London.

Jono, 2010, Hukum Kepailitan, Sinar Grafika, Jakarta

Muhammad, Abdulkadir, Hukum Perusahaan Indonesia, cetakan ke4, PT Citra Aditya Bakti, Bandung.

Nating, Imran, 2005, Peranan dan Tanggung Jawab Kurator dalam Pengurusan dan Pemberesan Harta Pailit, PT Raja Grafindo, Jakarta

${ }^{1}$ Lihat Pasal 75 UUPT 2007. 
Subekti, R. dan R. Tjitrosudibio, 2002, Kitab Undang-Undang Hukum Perdata, Pradnya Paramita, Jakarta.

\section{Artikel Ilmiah}

Resen, Made Gde Subha Karma, 2015, Pengaturan Badan Usaha Milik Daerah Berdasarkan Good Governance dan Good Corporate Governance (Tinjauan Yuridis Terhadap Badan Usaha Milik Daerah Sebagai Entitas Bisnis), Desertasi, Fakultas Hukum Universitas Gadjah Mada.

Wijayanta, Tata, 2013, Kajian Tentang Syarat Kepailitan Menurut UndangUndang Nomor 37 Tahun 2004, Hasil penelitian Fakultas Hukum Universitas Gadjah Mada.

\section{Artikel Internet}

Linda Hairani, "Kasus Pailit, Telkomsel

Menang Lagi di MA", diakses pada 24

Januari 2017, diakses melalui

https://m.tempo.co/read/news/2013/

07/22/090498741/kasus-pailit-

telkomsel-menang-lagi-di-ma

\section{Peraturan Perundang-Undangan}

Undang-Undang Dasar Negara Republik Indonesia 1945

Undang Nomor 17 Tahun 2003 tentang Keuangan Negara (Lembaran Negara Republik Indonesia Tahun 2013 Nomor 47, Tambahan Lembaran Negara Republik Indonesia Nomor 4286)

Undang-Undang Nomor 23 Tahun 2003 tentang Badan Usaha Milik Negara (Lembaran Negara Republik Indonesia Tahun 2003 Nomor 70, Tambahan Lembaran Negara Republik Indonesia Nomor 4297)

Undang 37 Tahun 2004 tentang Kepailitan dan Penundaan Kewajiban Pembayaran Utang (Lembaran Negara Republik
Indonesia Tahun 2004 Nomor 131, Tambahan Lembaran Negara Republik Indonesia Nomor 4443) Undang-Undang Nomor 40 Tahun 2007 tentang Perseroan Terbatas (Lembaran Negara Republik Indonesia Tahun 2007 Nomor 106, Tambahan Lembaran Negara Republik Indonesia Nomor 4756) 